\title{
The effects of a sports nutrition education intervention on nutritional status, sport nutrition knowledge, body composition, and performance in NCAA Division I baseball players
}

\author{
Jason M Cholewa ${ }^{1 *}$, Andrew Landreth'1, Stacy Beam¹, Taylor Jones², Christopher J MacDonald \\ From The Twelfth International Society of Sports Nutrition (ISSN) Conference and Expo \\ Austin, TX, USA. 11-13 June 2015
}

\section{Background}

Maintaining energy balance by consuming the required distribution of macronutrients (nutritional status) is important to support performance and health in collegiate athletes; however, less than 10\% of NCAA athletes possess adequate sports nutrition knowledge or maintain nutritional status (Torres-McGehee et al., 2012). A recent study demonstrated that a sports nutrition education intervention (SNEI) improved nutritional knowledge and nutritional status in Division I volleyball players. This study investigated the effects of an SNEI on nutritional status, knowledge, body composition, and performance in NCAA Division I baseball players.

\section{Methods}

Thirty resistance trained NCAA Division I baseball players $(82.4 \pm 8.2 \mathrm{~kg} ; 183 \pm 6.3 \mathrm{~cm} ; 13.7 \pm 5 \%$ bodyfat $)$ participated in the 12-week study. Fifteen players volunteered for the SNEI while 15 players matched for position served as controls (C). All players participated in a monitored, periodized strength ( $4 \mathrm{hr} / \mathrm{wk}$ ), conditioning $3 \mathrm{hr} / \mathrm{wk}$ ), and skills $(20 \mathrm{hr} / \mathrm{wk})$ training program. The nutrition intervention group $(\mathrm{N})$ received a 90 min SNEI encompassing the following topics: energy intake (Kcal), carbohydrate $(\mathrm{CHO})$, protein (PRO), fat, food sources, and hydration. Thereafter, $\mathrm{N}$ met once every three weeks with the primary researcher for educational reinforcement in groups of 5. Sport nutrition knowledge questionnaires (Reilly \& Maughan, 2007) were administered to $\mathrm{N}$ at baseline ( $\mathrm{t}-0$ )

\footnotetext{
* Correspondence: jcholewa@coastal.edu

'Department of Kinesiology, Coastal Carolina University, Conway, SC 29528, USA

Full list of author information is available at the end of the article
}

and following 12 weeks (t-12). Food intake was determined by three-day dietary logs administered to $\mathrm{N}$ at $\mathrm{t}-0$ and $\mathrm{t}-12$. Energy and macronutrient intake was calculated using Diet Analysis Plus (Cengage), and compared to nutritional requirements (Kcal: $45 \mathrm{kcal} / \mathrm{kg}$; PRO: $2 \mathrm{~g} / \mathrm{kg}$; CHO $6 \mathrm{~g} / \mathrm{kg}$; Fat $1.5 \mathrm{~g} / \mathrm{kg}$ ). Body composition (BodPod), 1 RM back squat, vertical jump, and broad jump were measured at $\mathrm{t}-\mathrm{O}$ and $\mathrm{t}-12$ for $\mathrm{C}$ and $\mathrm{N}$. Pre and post nutritional status and knowledge were analyzed using paired samples t-test for $\mathrm{N}$. Changes in body composition and performance were compared between $\mathrm{C}$ and $\mathrm{N}$ using an independent groups t-test with an alpha level of 0.05 for all tests.

\section{Results}

Knowledge significantly $(\mathrm{p}<0.05)$ increased from $\mathrm{t}-0$ to t-12 (56 $\pm 11 \%$ vs. $70 \pm 9 \%)$. Energy consumption was significantly $(\mathrm{p}<0.05)$ less than requirements at $\mathrm{t}-0$ $(35.5 \pm 6.6 \mathrm{kcal} / \mathrm{kg})$ and significantly $(\mathrm{p}<0.05)$ increased to meet requirements at $\mathrm{t}-12(41.2 \pm 5.2 \mathrm{kcal} / \mathrm{kg})$. $\mathrm{CHO}$ was significantly $(\mathrm{p}<0.05)$ less than requirements at $\mathrm{t}-0$ $(3.6 \pm 1.1 \mathrm{~g} / \mathrm{kg})$ and $\mathrm{t}-12(3.8 \pm 0.8 \mathrm{~g} / \mathrm{kg})$. PRO was significantly $(\mathrm{p}<0.05)$ less than requirements at $\mathrm{t}-0(1.7 \pm 0.4$ $\mathrm{g} / \mathrm{kg})$ and significantly increased $(\mathrm{p}<0.05)$ at $\mathrm{t}-12(2.2 \pm$ $0.4 \mathrm{~g} / \mathrm{kg}$ ). Fat was not significantly $(\mathrm{p}>0.05)$ different than requirements at $\mathrm{t}-0(1.6 \pm 0.3 \mathrm{~g} / \mathrm{kg})$ and significantly $(\mathrm{p}<$ $0.05)$ increased above requirements at $\mathrm{t}-12(2.0 \pm 0.4$ $\mathrm{g} / \mathrm{kg})$. Fat free mass and body mass significantly $(\mathrm{p}<0.05)$ increased $(\Delta=3.7 \pm 3.6 \mathrm{~kg} ; 3.3 \pm 4.8 \mathrm{~kg}$, respectively) with no difference between groups. Percent body fat decreased significantly $(\mathrm{p}<0.05)$ in $\mathrm{N}(\Delta=-1.2 \pm 2.3 \%)$ but not $\mathrm{C}$ $(\Delta=0.3 \pm 1.7 \%)$. Squat, vertical, and broad jump 
significantly $(\mathrm{p}<0.05)$ increased $(\Delta=25.5 \pm 15.9 \mathrm{~kg}$; $.144 \pm 0.09 \mathrm{~m} ; .135 \pm 0.1 \mathrm{~m}$, respectively) with no difference between groups.

\section{Conclusion}

Our findings indicate that an off season SNEI is effective at improving sport nutrition knowledge and some, but not all nutrient intakes in Division I baseball players. Improvements in nutritional status were associated with decreases in body fat percentage, possibly attributable to increased protein consumption.

\section{Authors' details}

${ }^{1}$ Department of Kinesiology, Coastal Carolina University, Conway, SC 29528,

USA. ${ }^{2}$ Speed, Strength and Conditioning, Coastal Carolina University,

Conway, SC 29528, USA.

Published: 21 September 2015

doi:10.1186/1550-2783-12-S1-P44

Cite this article as: Cholewa et al:: The effects of a sports nutrition education intervention on nutritional status, sport nutrition knowledge, body composition, and performance in NCAA Division I baseball players. Journal of the International Society of Sports Nutrition 2015 12(Suppl 1):P44.

Submit your next manuscript to BioMed Central and take full advantage of:

- Convenient online submission

- Thorough peer review

- No space constraints or color figure charges

- Immediate publication on acceptance

- Inclusion in PubMed, CAS, Scopus and Google Scholar

- Research which is freely available for redistribution

Submit your manuscript at www.biomedcentral.com/submit 